\title{
The polymorphism in g.1256G $>$ A of bovine pituitary specific transcription factor-1 (bPIT-1) gene and its association with body weight of Pasundan cattle
}

\author{
W. P. B. Putra*, P. P. Agung and S. Said \\ Research Center for Biotechnology - Indonesian Institute of Sciences (LIPI), \\ Jl. Bogor-Jakarta Km 46 Cibinong, Bogor, West Java 16911- Indonesia \\ *Corresponding E-mail: widya.putra.lipi@gmail.com
}

Received July 04, 2018; Accepted October 06, 2018

\begin{abstract}
ABSTRAK
Bovine Pituitary specific transcription factor 1 (bPit-1) merupakan suatu asam amino yang berfungsi untuk mengontrol perkembangan kelenjar pituitary pada sapi. Kelenjar pituitary berfungsi untuk mensekresikan hormon pertumbuhan yang dihasilkan oleh gen-gen pertumbuhan. Penelitian ini bertujuan untuk mendeteksi polimorfisme pada ekson 6 gen bPit-1 (g. 1256G>A) dengan metode PCR$R F L P$ dan mengetahui pengaruhnya terhadap berat badan sapi Pasundan. Sampel yang digunakan sebanyak 69 ekor (15 jantan dan 54 betina) dan berasal dari pusat pembibitan (BPPIBT-SP Ciamis, Jawa Barat). Hasil penelitian menunjukkan bahwa terdapat dua genotipe gen bPit-1/Hinfl pada sapi Pasundan di pusat pembibitan (BPPIBT-SP Ciamis, Jawa Barat) yaitu GG $(0,90)$ dan AG $(0,10)$ dengan frekuensi alel sebesar 0,05 (A) dan 0,95 (G). Nilai polymorphism informative content (PIC) dan jumlah alel efektif $\left(\mathrm{n}_{\mathrm{e}}\right)$ yang diperoleh masing-masing sebesar 0,09 (rendah) dan 1,11 . Nilai Chi-square $\left(\chi^{2}\right)$ pada populasi sampel sebesar 0,20 dan masih dalam keseimbangan Hardy-Weinberg $\left(\chi^{2}<5,99\right)$. Disimpulkan bahwa polimorfisme pada gen bPit-1/Hinfl sapi Pasundan di pusat pembibitan termasuk rendah dan tidak berasosiasi dengan berat badan.
\end{abstract}

Kata kunci: sapi Pasundan, gen bPit-1, PCR-RFLP, berat badan

\begin{abstract}
Bovine Pituitary specific transcription factor 1 (bPit-1) is one of amino acid that controling pituitary gland in mammals. The pituitary gland is important for secretion of growth hormone from growth genes. This study was carried out to detect polymorphism in the exon 6 of bPit-1 (g.1256G $>A$ ) in Pasundan cattle using PCR-RFLP method and its association with body weight. Total of 69 heads (15 males and 54 females) of Pasundan cattle from breeding station (BPPIBT-SP Ciamis, West Java) were used in this study. Research showed that two genotypes of bPit-1/Hinfl gene were identified in this study i.e GG (0.90) and AG (0.10) with allele frequencies of 0.05 (A) and 0.95 (G). The polymorphic informative content (PIC) and number of effective allele $\left(\mathrm{n}_{\mathrm{e}}\right)$ values were 0.09 (low) and 1.11. respectively. The Chi-square $\left(\chi^{2}\right)$ value in the population studied was 0.20 and in Hardy-Weinberg equilibrium $\left(\chi^{2}<5.99\right)$. It was concluded that the polymorphism of bPit-1/Hinfl in Pasundan cattle included of low category and was not associated with body weight.

Keywords: Pasundan cattle, bPit-1 gene, PCR-RFLP, body weight
\end{abstract}




\section{INTRODUCTION}

Pasundan cattle is one of native cattle in Indonesia decided by Ministry of Agriculure No: 1051/Kpts/SR.120/10/2014. Pasundan cattle was created from crossbreding between Bos indicus and Bos javanicus since hundred years ago. This cattle was adapted well in West Java Province and kept by the farmers as beef cattle. Recently, the genetic improvement of Pasundan cattle was supported by local gevernment through breeding station of Balai Pengembangan Perbibitan dan Inseminasi Buatan Ternak - Sapi Potong (BPPIBT-SP) Ciamis, West Java. As the Pasundan breeding center, BPPIBT-SP Ciamis must be capable to increase livestock's productivity through livestock selection. Recently, livestock selection can be conducted based on single nucleotide polymorphism (SNP) in the gene that controling productivity and called as the candidate gene (Dekkers, 2004; Van Eenennaam et al., 2007).

There are many growth hormone family genes that were used as molecular selection in cattle i.e. insulin-like growth factor 1 (IGF-1), insulin-like growth factor binding protein 3 (IGFBP-3), growth hormone (GH), growth hormone receptor (GHR), growth hormone releasing hormone (GHRH) and pituitary specific transcription factor (Pit-1) genes. The bovine Pit1 gene is one of the candidate gene that potential for molecular selection in cattle (Sumantri et al., 2011; Oner et al., 2017). The bPit-1 gene was located at centromeric region of chromosome 1 (1q21-22) and consists of five introns and six exons (Woollard et al., 2000). The bPit-1 gene was synthesized at anterior pituitary gland and has 291 amino acid protein $(31-33 \mathrm{kDa})$ with DNA binding POU domain class 1 transcription factor 1 (POUF1) that is responsible for pituitary development and hormone secreting gene expression in mammals, activating expression of growth hormone, prolactin and thyrotropin $\beta$ subunit genes (de Mattos et al., 2004).

Previous studies reported that one SNP was in the exon 6 of bPit-1 gene at position g.1256G $>A$ based on GenBank: Y15995 (Javanmard et al., 2005; Misrianti et al., 2010; Aytekin and Boztepe, 2013; Nahavandi et al., 2010; Chauhan et al., 2015; Bayram et al., 2017). Moreover, SNP of g.1256G $>$ A can be detected by Hinfl restriction enzyme through PCR-RFLP method (Dybus et al., 2003). Several studies reported that polymorphism of bPit-1/HinfI were associated with growth traits in Canchim (Carrijo et al., 2008) and fat percentage in dairy Gyr (de Mattos et al., 2004). Despite, many researches also reported that polymorphism of bPit-1/Hinf I were not associated with milk performance traits in Slovak Simmental (Trakovicka et al., 2015), Brown Swiss (Aytekin and Boztepe, 2013), Friesian Holstein (Heidari et al., 2012), Hoseinzadeh et al., 2015; Ozdemir et al., 2016) and Polish Black and White (Dybus et al., 2004), growth and carcass traits in crossbred cattle (Curi et al., 2006), body weight and body measurements in Limousine cattle (Dybus et al., 2003) and superovulation response in Friesian Holstein (Sumantri et al., 2011).

Identification genotype of bPit-1/Hinfl gene in Pasundan cattle is important as the basic information for molecular selection in the future. Despite, the information regarding to bPit-1 gene of Pasundan cattle so far is not reported. The objectives of this study were to identify the polymorphism in the exon 6 of bPit- 1 gene and to investigate the influence of genotype type related to body weight in a herd of Pasundan cattle.

\section{MATERIALS AND METHODS}

\section{Blood Samples and DNA Extraction}

A total of 69 heads of Pasundan cattle (15 males and 54 females) from breeding station (BPPIBT-SP Ciamis, West Java Province) were used for blood sampling purpose. Blood samples (3-5 $\mathrm{mL})$ were taken from cocygeal vein using venoject and collected in vaccutainer tubes containing anticoagulant (K2EDTA). The blood samples were used in the DNA extraction kit process using the Genomic DNA Mini kit (Geneaid Biotech Ltd., Taiwan) following the manufactures instruction. The extracted DNA was recorded and stored at $-20^{\circ} \mathrm{C}$ for next analysis.

\section{PCR Amplification of bPit-1 Gene}

The primer sequences for PCR analysis was adoped from Nahavandi et al. (2010) i.e Pit-1F: 5'-GAGCCTACATGAGACAAGCATC-3' and Pit-1R: 5'-AAATGTACAATGTGCCTTCTGA3'. This primer was amplifed Pit-1 gene along 610 bp according to the reference sequence (Figure 1). The polymerase chain reaction (PCR) reagents were as follows: $2.7 \mu \mathrm{L}$ of KAPA2G Robust PCR Kit (Kapa Biosystems, Cape Town, South Africa); each $0.80 \mu \mathrm{L}$ of forward and reverse primers (200 $\mathrm{ng} / \mu \mathrm{L}) ; 2.0 \mu \mathrm{L}$ of DNA samples; and $\mathrm{ddH} 2 \mathrm{O}$ up to $7.0 \mu \mathrm{L}$. The PCR was carried out in 


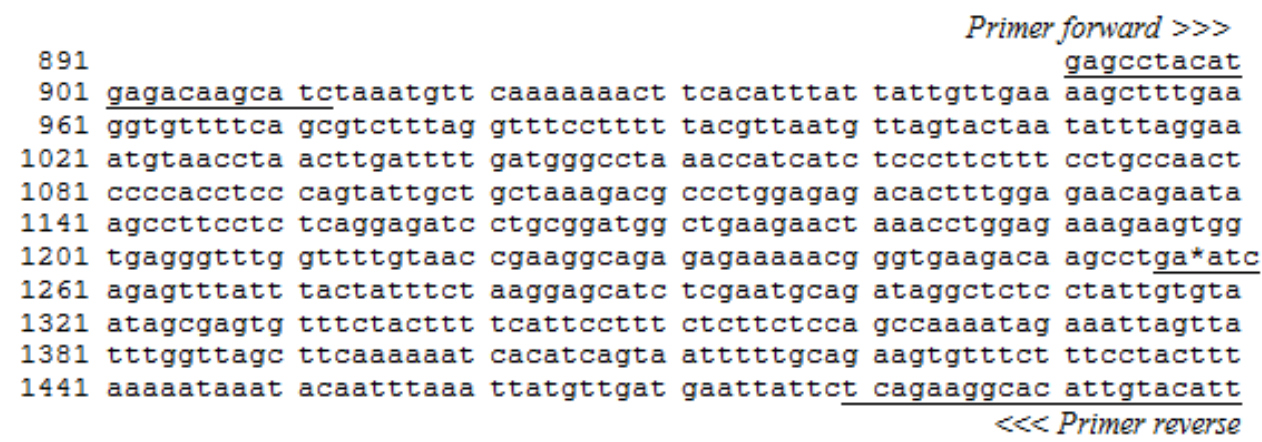

Figure 1. The primer position (underline) and Hinfl restriction enzyme site (ga*Ntc) in bPit-1 gene based on combination sequences from GenBank: Y15995 (891-1301) and AM490263 (1302-1500).

mastercycler gradient machine (Eppendorf, Germany). The PCR program was set up as follows: initial denaturation at $94^{\circ} \mathrm{C}$ for 5 minutes; denaturation at $94^{\circ} \mathrm{C}$ for 30 seconds; annealing at $64^{\circ} \mathrm{C}$ for 30 seconds; initial extension at $72^{\circ} \mathrm{C}$ for 30 seconds and final extension at $72^{\circ} \mathrm{C}$ for 5 minutes. The PCR product was visualized using $1.0 \%$ agarose gel (Vivantis, Malaysia). The gel was stained with GelRed ${ }^{\mathrm{TM}}$ (Biotium, USA). Total $3.0 \mu \mathrm{L}$ of $100 \mathrm{bp}$ DNA ladder (Vivantis, Malaysia) was used as molecular size marker. The electrophoresis $(110 \mathrm{~V} ; 30$ minutes) analysis was used for visualization PCR product with GBOX Documentation System (Syngene, UK).

\section{Genotyping of bPit-1 Gene using RFLP Technique}

Analysis of restriction fragment length polymorphism (RFLP) was applied for genotyping of Pit-1 gene in this study. The mixture was consisted of $4.20 \mu \mathrm{L}$ of PCR product; $0.28 \mu \mathrm{L}$ of Hinfl restriction enzyme (GA*NTC); $0.70 \mu \mathrm{L}$ buffer and $\mathrm{ddH}_{2} \mathrm{O}$ up to $7.0 \mu \mathrm{L}$. Then, the mixtures were incubated at $37^{\circ} \mathrm{C}$ for $1 \mathrm{~h}$. Digested products were analyzed using electrophoresis (110 $\mathrm{V} ; 1 \mathrm{~h}$ ) on $2.0 \%$ agarose gel with $3.0 \mu \mathrm{L}$ of $100 \mathrm{bp}$ DNA ladder. The digested product was stained with GelRed $^{\mathrm{TM}}$ and captured with GBOX Documentation System. Samples with AA genotypes were consisted of one DNA fragment (610 bp). Samples with AG genotype consisted of three DNA fragments $(610 \mathrm{bp}, 367 \mathrm{bp}$ and 243 bp). While, samples with GG genotype consisted of two DNA fragments (367 bp and $243 \mathrm{bp}$ ).

\section{Statistical Analysis}

Data of body weight (BW) were analyzed applying a linear mixed model as follows:

$\mathrm{Y}_{\mathrm{i}}=\mu+\mathrm{G}_{\mathrm{i}}+\mathrm{e}_{\mathrm{i}}$

Where:

$\mathrm{Y}_{\mathrm{i}} \quad$ : dependent variable (BW)

$\mu \quad$ : overall mean

$\mathrm{G}_{\mathrm{i}}$ : fixed effect of the $\mathrm{j}^{\text {th }}$ genotype (AA, AG, GG)

$\mathrm{e}_{\mathrm{i}} \quad$ : random residual effect

The genotype data of in all samples were used to estimate allele frequencies, heterozigosity, polymorphic informative content (PIC), number of effective allele $\left(\mathrm{n}_{\mathrm{e}}\right)$ and Chi-square $\left(\chi^{2}\right)$ values as follow:

The allele frequencies were calculated using formula from Sadeghi et al. (2008) as follows:

$$
\mathrm{X}_{\mathrm{i}}=\frac{2\left(\mathrm{~N}_{\mathrm{ii}}\right)+\left(\mathrm{N}_{\mathrm{ij}}\right)}{2 \mathrm{~N}}
$$

Where:

$\mathrm{X}_{\mathrm{i}}$ : frequency of $\mathrm{i}^{\text {th }}$ allele

$\mathrm{N}_{\mathrm{ii}}$ : number of genotype $\mathrm{A}_{\mathrm{i}} \mathrm{A}_{\mathrm{i}}$

$\mathrm{N}_{\mathrm{ij}}$ : number of genotype $\mathrm{A}_{\mathrm{i}} \mathrm{A}_{\mathrm{j}}$

$\mathrm{N}$ : number of observation

The heterosigosity values were calculated using formula from Nei and Kumar (2000) as follows:

$$
\mathrm{H}_{\mathrm{e}}=1-\sum_{i=1}^{n} \mathrm{X}_{\mathrm{i}}^{2}
$$

and

$$
\mathrm{SE}=\sqrt{\operatorname{Var}_{\mathrm{He}}}
$$




$$
\begin{aligned}
& \operatorname{Var}_{\mathrm{He}}=\frac{2}{2(2 \mathrm{n}-1)} \mathrm{X} \\
& \mathrm{X}=\left[2(2 \mathrm{n}-2)\left(\sum \mathrm{X}_{i}^{3}-\left(\sum \mathrm{X}_{\mathrm{i}}^{2}\right)^{2}\right)+\left(\sum \mathrm{X}_{\mathrm{i}}^{2}-\left(\sum \mathrm{X}_{\mathrm{i}}^{2}\right)^{2}\right)\right] \\
& \mathrm{H}_{\mathrm{o}}=\frac{\mathrm{X}_{\mathrm{ij}}}{\mathrm{N}}
\end{aligned}
$$

Where:

$\mathrm{H}_{\mathrm{e}}$ : expected heterozigosity

$\mathrm{H}_{\mathrm{o}}$ : observed heterozigosity

$X_{i}$ : frequency of $i^{\text {th }}$ allele

$X_{i j}$ : frequency of heterozygote genotype

$\mathrm{N}$ : number of observation

SE : standard error

The PIC value was calculated using formula from Hildebrand et al. (1992) as follows:

$$
\mathrm{PIC}=1-\sum_{i=1}^{n} \mathrm{X}_{\mathrm{i}}^{2}-\sum_{i=1}^{n-1} \sum_{j=i+1}^{n} 2 \mathrm{X}_{\mathrm{i}}^{2} \mathrm{X}_{\mathrm{j}}^{2}
$$

PIC : polymorphic informative content

$X_{i}$ : frequency of $i^{\text {th }}$ allele

$X_{j}$ : frequency of $j^{\text {th }}$ allele

The $\mathrm{n}_{\mathrm{e}}$ value was calculated using formula from Nei and Kumar (2000) as follows:

$$
\mathrm{n}_{\mathrm{e}}=\frac{1}{\sum_{\mathrm{i}=1}^{\mathrm{n}} \mathrm{X}_{\mathrm{i}}^{2}}
$$

Where:

$\mathrm{n}_{\mathrm{e}} \quad$ : number of effective allele

$\mathrm{X}_{\mathrm{i}} \quad$ : frequency of $\mathrm{i}^{\text {th }}$ allele

The $\chi^{2}$ value was calculated using formula from Nei and Kumar (2000) as follows:

$$
\chi^{2}=\sum_{i=1}^{n} \frac{\left(\mathrm{O}_{\mathrm{i}}-\mathrm{E}_{\mathrm{i}}\right)^{2}}{\mathrm{E}_{\mathrm{i}}}
$$

Where:

$$
\begin{array}{ll}
\chi^{2} & \text { : Chi-square value } \\
\mathrm{O}_{\mathrm{i}} & : \text { number of observed } \mathrm{i}^{\text {th }} \text { genotype } \\
\mathrm{E}_{\mathrm{i}} & \text { : numberof expected } \mathrm{i}^{\text {th }} \text { genotype }
\end{array}
$$

\section{RESULTS AND DISCUSSION}

The Pit-1 gene fragments was successfully amplified using PCR technique for all sample and resulted in a single product of $610 \mathrm{bp}$ (Figure 2). The RFLP analysis showed the fragments obtained for the bPit-1/Hinfl polymorphism were 367 and 243 bp for GG genotype; 610, 367 and $243 \mathrm{bp}$ for the AB genotype as presented in Figure 3. The statistical analysis for bPit-1/Hinf polymorphism is presented in Table 1. Genotype AA (610 bp) was not observed in this study and similar to the other breeds cattle such as Golpayegani $\times$ Brown Swiss (Javanmard et al., 2005) and Gyr (de Mattos et al., 2004). Despite, Jakaria and Noor (2015) reported that AA genotype in the bPit-1/Hinfl gene are absence in many Indonesian native cattle such as Aceh, Katingan and Bali cattle. Therefore, the frequency of AG genotype in this study was 0.10 and similar to Katingan (Jakaria and Noor, 2015). The frequency of A allele in the present study was under 0.10 and similar to native cattle in Indonesia (Madura, Pesisir, Aceh, Katingan, Bali) and Brazil (Gyr) is presented in Table 2.

The PIC value in the present study is low $(\mathrm{PIC}<0.25)$ and describes that the genetic diversity of bPit-1/Hinfl is not effective for

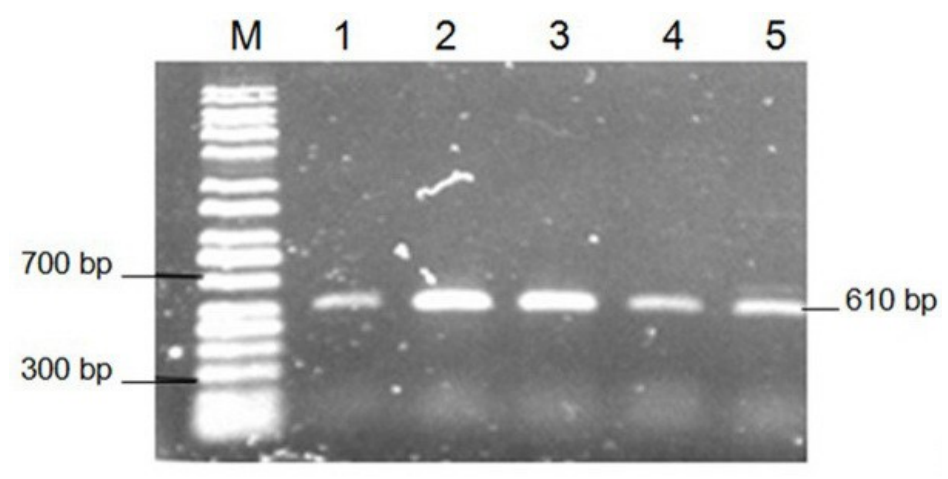

Figure 2. The amplification of bPit-1 gene showed on1\% agarose gel. M: DNA ladder $100 \mathrm{bp}$; lanes 1-5: PCR products amplified from DNA of animal studied 


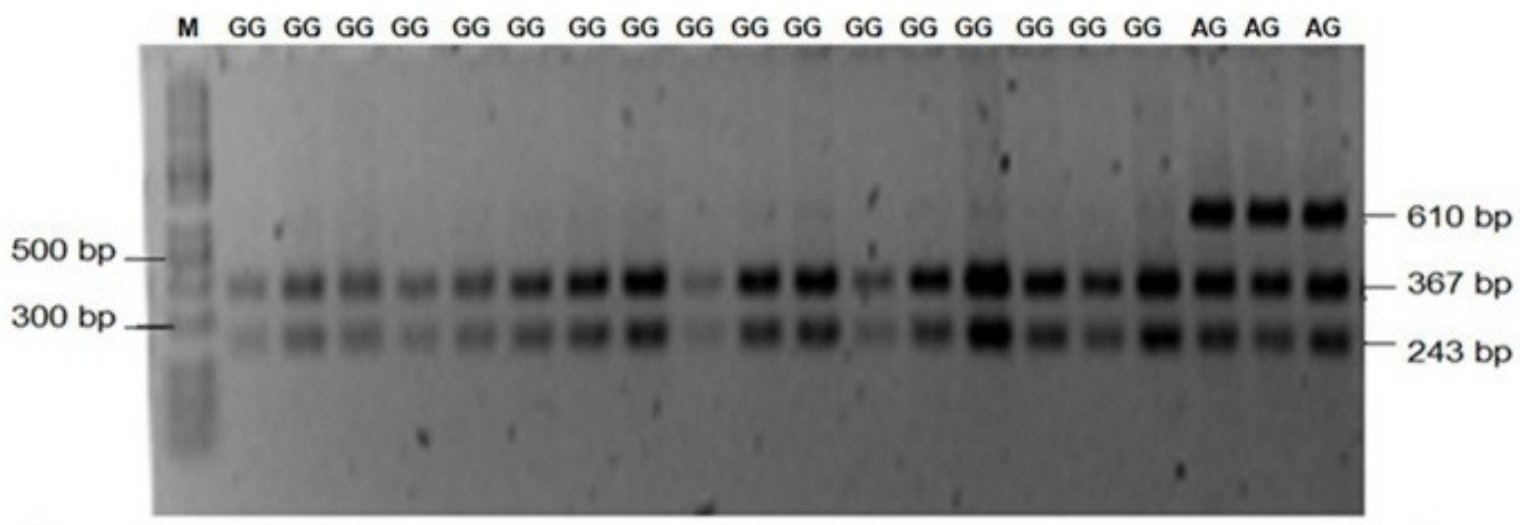

Figure 3. The result of PCR-RFLP analysis in bPit-1/Hinfl gene of Pasundan cattle separated on 2\% agarose gel consisted of two genotypes of GG (367 bp and $243 \mathrm{bp}$ ) and AG (610 bp, $367 \mathrm{bp}$ and 243 bp). M: DNA ladder $100 \mathrm{bp}$

Table 1. Genetic Characterization in the Exon 6 of bPit-1/Hinfl Gene in Pasundan Cattle at the Breeding Station

\begin{tabular}{|c|c|c|c|c|c|c|c|c|c|}
\hline \multicolumn{3}{|c|}{$\begin{array}{c}\text { Genotype Frequency } \\
\text { (N) }\end{array}$} & \multicolumn{2}{|c|}{ Allele Frequency } & \multirow{2}{*}{$\begin{array}{l}\mathrm{H}_{\mathrm{e}} \\
(\mathrm{SE})\end{array}$} & \multirow{2}{*}{$\mathrm{H}_{\mathrm{o}}$} & \multirow{2}{*}{ PIC } & \multirow{2}{*}{$\mathrm{n}_{\mathrm{e}}$} & \multirow{2}{*}{$\chi^{2}$} \\
\hline AA & $\mathrm{AG}$ & GG & A & G & & & & & \\
\hline $\begin{array}{c}0.00 \\
(0)\end{array}$ & $\begin{array}{r}0.10 \\
(7)\end{array}$ & $\begin{array}{l}0.90 \\
(62)\end{array}$ & 0.05 & 0.95 & $\begin{array}{l}0.10 \\
(0.07)\end{array}$ & 0.10 & 0.09 & 1.11 & $0.20^{*}$ \\
\hline
\end{tabular}

$\mathrm{N}=$ number of sample; $\mathrm{SE}=$ standard error; $\chi^{2}=$ Chi square value; $\mathrm{H}_{\mathrm{e}}=$ expected heterozigosity; $\mathrm{H}_{\mathrm{o}}=$ observed heterozigosity; PIC $=$ polymorphism informative content; $\mathrm{n}_{\mathrm{e}}=$ number of effective allele; * under HardyWeinberg equilibrium $\left(\chi_{2 ; 0.05}^{2}=5.99\right)$

molecular selection in Pasundan cattle. Low PIC value in the bPit-1/Hinfl of Pasundan cattle can be affected by selection system in smallholder farmer. Moreover, limitation number of sires in the population might be caused the low value of PIC (Agung et al., 2017). The $\mathrm{n}_{\mathrm{e}}$ value of bPit-

1/Hinfl gene in Pasundan cattle was 1.11 and reveals that $\mathrm{B}$ allele as the dominant allele in this gene. The genetic diversity of bPit-1/Hinfl gene in the animal studied under Hardy-Weinberg (HW) equilibrium and can be caused by random mating still occured in the research site. The $\mathrm{H}_{\mathrm{o}}$ and $\mathrm{H}_{\mathrm{e}}$ values in the present study was similar $(0.10)$ and reveal that the animal studied under HW equilibrium. Body weight of Pasundan cattle in GG genotypes was not significantly different from AG genotypes (Table 3). No association between bPit-1/Hinfl gene polymorphism and body weight in the present study might be caused by low number of sample.
Dybus et al. (2003) reported that in polymorphism of bPit-1/Hinfl gene was not associated with body weight in Limousine cattle and similar to the present study. In contrast, Renaville et al. (1997a) reported that A allele in the bPit-1/Hinfl gene was found to be superior for milk traits and body measurements in Italian Frieasian Holstein. Morever, Sumantri et al. (2011) reported that genotype AA in the bPit1/Hinfl gene of $\mathrm{FH}$ cows had the highest of ovulation rate rather than other genotypes.

The bPit-1/Hinfl gene of Pasundan cattle in this study can not be used as molecular selection for body weight. Detection of the polymorphism in the other region of bPit-1 gene i.e. 5'UTR/ promotor, other exons, intron and $3^{\prime} \mathrm{UTR}$ is important to obtain the genetic marker for productivity traits through marker assisted selection (MAS) program in the future. 
Table 2. Polymorphism of the Exon 6 of bPit-1/Hinfl Gene with Different PCR Product according to the Previous Study

\begin{tabular}{|c|c|c|c|c|c|c|c|c|c|}
\hline \multirow[t]{2}{*}{ Breed } & \multirow[t]{2}{*}{ Species } & \multirow[t]{2}{*}{ Location } & \multirow[t]{2}{*}{$\mathrm{N}$} & \multirow{2}{*}{$\begin{array}{l}\text { PCR } \\
\text { product } \\
\text { (bp) }\end{array}$} & \multicolumn{3}{|c|}{$\begin{array}{l}\text { Genotype } \\
\text { frequency }\end{array}$} & \multicolumn{2}{|c|}{$\begin{array}{c}\text { Allele } \\
\text { frequency }\end{array}$} \\
\hline & & & & & $\overline{\mathrm{AA}}$ & AG & GG & $\bar{A}$ & $\bar{G}$ \\
\hline Holstein-Friesian $^{1}$ & Bos taurus & Indonesia & 45 & 610 & 0.02 & 0.44 & 0.53 & 0.25 & 0.75 \\
\hline Brown Swiss $^{2}$ & Bos taurus & Turkey & 301 & 610 & 0.12 & 0.51 & 0.37 & 0.37 & 0.63 \\
\hline $\mathrm{Sarabi}^{3}$ & Bos taurus & Iran & 82 & 610 & 0.45 & 0.34 & 0.21 & 0.68 & 0.38 \\
\hline Golpayegani x Brown Swiss ${ }^{4}$ & Bos taurus & Iran & 13 & 610 & 0.00 & 0.77 & 0.23 & 0.38 & 0.62 \\
\hline Turkish Holstein-Friesian5 & Bos taurus & Turkey & 352 & 610 & 0.18 & 0.29 & 0.53 & 0.32 & 0.68 \\
\hline Slovak Simmental $^{6}$ & Bos taurus & Slovakia & 288 & 260 & 0.05 & 0.35 & 0.60 & 0.23 & 0.77 \\
\hline Slovak Spotted Cattle ${ }^{7}$ & Bos taurus & Slovakia & 110 & 260 & 0.05 & 0.50 & 0.45 & 0.30 & 0.70 \\
\hline Holstein-Friesian8 & Bos taurus & Turkey & 181 & 260 & 0.04 & 0.31 & 0.65 & 0.20 & 0.80 \\
\hline East Anatolian Red9 & Bos taurus & Turkey & 71 & 451 & 0.14 & 0.54 & 0.32 & 0.41 & 0.59 \\
\hline Italian Holstein-Fr. bull ${ }^{10}$ & Bos taurus & Italia & 89 & 451 & 0.02 & 0.32 & 0.55 & 0.19 & 0.81 \\
\hline Belgian Blue $^{11}$ & Bos taurus & Belgia & 350 & 451 & 0.20 & 0.45 & 0.35 & 0.42 & 0.58 \\
\hline Angus $^{12}$ & Bos taurus & USA & 416 & 451 & 0.11 & 0.44 & 0.45 & 0.33 & 0.67 \\
\hline Polish Black and White ${ }^{13}$ & Bos taurus & Poland & 900 & 451 & 0.05 & 0.38 & 0.57 & 0.24 & 0.76 \\
\hline Iranian Holstein-Fr. cow ${ }^{14}$ & Bos taurus & Iran & 262 & 451 & 0.03 & 0.45 & 0.52 & 0.26 & 0.74 \\
\hline Chilean Holstein-Fr. ${ }^{15}$ & Bos taurus & Chile & 46 & 451 & 0.10 & 0.35 & 0.55 & 0.28 & 0.72 \\
\hline Qinchuan $^{16}$ & Bos taurus & China & 218 & 451 & 0.03 & 0.40 & 0.57 & 0.23 & 0.77 \\
\hline Limousine $^{17}$ & Bos taurus & Poland & 130 & 451 & 0.07 & 0.41 & 0.52 & 0.27 & 0.73 \\
\hline Podolica $^{18}$ & Bos taurus & Italy & 104 & 451 & 0.14 & 0.32 & 0.54 & 0.30 & 0.70 \\
\hline Holstein-Friesian ${ }^{19}$ & Bos taurus & Iran & 100 & 451 & 0.06 & 0.40 & 0.54 & 0.26 & 0.74 \\
\hline Sahiwal $^{20}$ & Bos indicus & India & 77 & 610 & 0.04 & 0.31 & 0.65 & 0.19 & 0.81 \\
\hline Najdi $^{21}$ & Bos indicus & Iran & 84 & 451 & 0.04 & 0.30 & 0.66 & 0.18 & 0.82 \\
\hline Madura $^{22}$ & Bos indicus & Indonesia & 68 & 451 & 0.00 & 0.07 & 0.93 & 0.04 & 0.96 \\
\hline Pesisir $^{22}$ & Bos indicus & Indonesia & 100 & 451 & 0.01 & 0.13 & 0.86 & 0.08 & 0.92 \\
\hline $\operatorname{Aceh}^{22}$ & Bos indicus & Indonesia & 25 & 451 & 0.00 & 0.08 & 0.92 & 0.04 & 0.96 \\
\hline Katingan ${ }^{22}$ & Bos indicus & Indonesia & 50 & 451 & 0.00 & 0.10 & 0.90 & 0.05 & 0.95 \\
\hline Nellore $^{23}$ & Bos indicus & Brazil & 79 & 1301 & 0.80 & 0.20 & 0.00 & 0.90 & 0.10 \\
\hline Canchim $^{24}$ & B. ind $x$ B. tau & Brazil & 219 & 1301 & 0.77 & 0.19 & 0.04 & 0.87 & 0.13 \\
\hline $\mathrm{Gyr}^{25}$ & B. indicus & Brazil & 40 & 1355 & 0.00 & 0.10 & 0.90 & 0.05 & 0.95 \\
\hline Bali $^{22}$ & Bos javanicus & Indonesia & 245 & 451 & 0.00 & 0.04 & 0.96 & 0.02 & 0.98 \\
\hline $\begin{array}{l}{ }^{9} \mathrm{Ozdemir}(201 \\
{ }^{14} \mathrm{Edriss} \text { et al. } \\
{ }^{19} \mathrm{Hoseinzadeh}\end{array}$ & . & (1) & 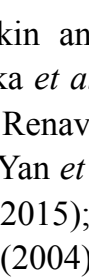 & 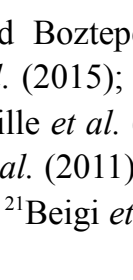 & 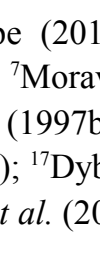 & 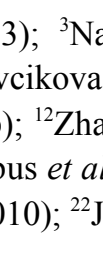 & & $a$ & 201 \\
\hline
\end{tabular}


Table 3. Association of bPit-1/Hinfl Gene polymorphism with Body Measurements and Body Weight of Pasundan Cattle at the Breeding Station

\begin{tabular}{cc}
\hline Group / Genotype & Body weight $(\mathrm{kg})$ \\
\hline Heifer $(1 \mathrm{PPI})$ & \\
GG $(\mathrm{N}=21)$ & $163.90 \pm 21.49$ \\
AG $(\mathrm{N}=3)$ & $184.33 \pm 22.81$ \\
Cow $(2$ PPI $)$ & \\
GG $(\mathrm{N}=23)$ & $232.97 \pm 23.92$ \\
AG $(\mathrm{N}=2)$ & $228.50 \pm 10.61$ \\
Bull (3 PPI) & \\
GG $(\mathrm{N}=8)$ & $362.88 \pm 39.81$ \\
AG $(\mathrm{N}=2)$ & $407.00 \pm 32.53$ \\
\hline
\end{tabular}

$\mathrm{PPI}=$ pairs of incisors; $\mathrm{N}=$ number of observation

\section{CONCLUSION}

Single nucleotide polymorphism of g. $1256 \mathrm{G}>\mathrm{A}$ in the bPit-1 gene had low of genetic diversity and was not associated with body weight in Pasundan cattle. The AA genotype was not detected in the present study. In addition, the A allele in bPit-1/Hinfl gene of animal studied included of rare allele with low frequency.

\section{ACKNOWLEDGMENTS}

This research was funded by Research Center for Biotechnology - Indonesian Institute of Sciences (LIPI) trough DIPA UNGGULAN LIPI 2017 scheme and supported by $\mathrm{BP}_{2} \mathrm{D}$ Jawa Barat. The authors would like to thank to all of the staff at BPPIBT-SP Ciamis, West Barat.

\section{REFERENCES}

Agung, P. P., S. Anwar, W. P. B. Putra, M. S. A. Zein, A. S. Wulandari, S. Said, and A. Sudiro. 2017. Association of growth hormone $(\mathrm{GH})$ gene polymorphism with growth and carcass in Sumba Ongole (SO) cattle. J. Indonesian Trop. Anim. Agric. 42(3):153-159.

Aytekin, I. and S. Boztepe. 2013.Associations of Pit-1 gene polymorphism with milk yield and composition traits in Brown Swiss cattle. J. Anim. Plant. Sci. 23(5):1281-1289.

Bayram, D., K. Arslan, B. Akyuz and K. M. Iscan. 2017. Identification of pituitary- specific transcription factor-1 (PIT-1) and leptin gene (LEP) polymorphism of Holstein cattle reared in Turkey. Ankara. Univ. Vet. Fak. Derg, 64(4):337-343.

Beigi, N. M. T., Z. Beyranvand, T. Hartatik, J. Fayazil and S. Tavakoli. 2010. The study of PIT1 gene polymorphism in the Najdi cattle using PCR-RFLP method. J. Anim. Vet. Adv. 5(1):68-70.

Carrijo, S. M., M. M. de Alencar, F. L. B. Toral and L. C. A. Regitano. 2008. Association of Pit1 genotypes with growth traits in Canchim cattle. Sci. Agric. 65(2):116-121.

Chauhan, A., M. Tiwari, S. P. Singh, D. Sharma, S. Kumar, R. Goel, A. Bhattacharya and V. Singh. 2015. Association of Pit-1 gene polymorphism with milk production traits in Sahiwal cattle. Indian. J. Anim. Sci. 85(6): 610-612.

Curi, R. A., D. A. Palmieri, L. Suguisawa, H. N. de Oliveira, A. C. Silveira and C. R. Lopes. 2006. Growth and carcass traits associated with GH1/AluI and POU1F1/HinfI gene polymorphisms in Zebu and crossbred cattle. Genet. Mol. Biol. 29(1):56-61.

de Mattos, K. K., S. N. Del Lama, M. L. Martinez and A. F. Freitas. 2004 Association of bGH and Pit- 1 gene variants with milk production traits in dairy Gyr bulls. Pesq. Agro. Bras. 39(2):147-150.

Dekkers, J. C. M. 2004. Commercial application of marker and gene-assisted selection in livestock. J. Anim. Sci. 82(E):313-318.

Dybus, A., M. Kmiec, Z. Sobek, W. Pietrzyk and B. Wisniewski. 2003. Associations between polymorphisms of growth hormone releasing hormone (GHRH) and pituitary transcription factor 1 (PIT1) genes and production traits of Limousine cattle. Arch. Tierz. 46(6): 527-534.

Dybus, A., I. Szatkowska, E. CzerniawskaPiątkowska, W. Grzesiak, J. Wójcik, E. Rzewucka and S. Zych. 2004. PIT1-HinfI gene polymorphism and its associations with milk production traits in polish Blackand-White cattle. Arch. Tierz. 47(6):557563.

Edriss, V., M. A. Edriss, H. R. Rahmani and B. E. Sayed-Tabatabaei. 2008. Pit-1 gene polymorphism of Holstein cows in Isfahan 
Province. Biotechnol. 7(2):209-212.

Hildebrand, C. E., D. C. Torney and R. P. Wagner. 1992. Informativeness of polymorphic DNA markers. Los Alamos Science. 20: 100-102.

Heidari, M., M. A. Azari, S. Hasini, A. Khanahmadi and S. Zerehdaran. 2012. Effect of polymorphic variants of GH, Pit-1, and $\beta-L G$ genes on milk production of Holstein cows. Russ. J. Genet. 48(4):417421.

Hoseinzadeh, Z. E., M. R. Mohammadabadi, A. E. Koshkuieh, A. Kezri and A. N. Noori. 2015. Association of Pit-1 gene with milk fat percentage in Holsten cattle. Iranian $\mathrm{J}$. Anim. Sci. 5(3):575-582.

Jakaria and R. R. Noor. 2015. Identification of a single nucleotide polymorphism at Hinf-1 enzyme restriction site of Pit-1 gene on Indonesian Bali population. Media Peternakan. 38(2):104-109.

Javanmard, A., N. Asadzadeh, M. H. Banabazi and J. Tavakolian. 2005. The allele and genotype frequencies of bovine pituitary specific transcription factor and leptin genes in Iranian cattle and buffalo populations using PCR-RFLP. Iranian. J. Biotechnol. 3(2):104-108.

Misrianti, R., C. Sumantri and A. Farajallah. 2010. Polymorphism identification of Pit1 gene in buffaloes (Bubalus bubalis) and Holstein-Friesian cows. Media Peternakan. 33(3):131-136.

Moravcikova, N., A. Trakovicka, M. Miluchova, J. Bujko, A. Navratilova. 2013. HinfI polymorphism of Pit-1 gene in Slovak Spotted cattle. JMBFS. 2(1):1883-1890.

Nahavandi, R., N. Asadzadeh, A. S. Farjam, S.M.N. Amin, P. Hafezamini and A. Javanmard. 2010. Comparison of DNA polymorphism of bovine pituitary specific transcription factor and leptin gene between Iranian Bos indicus and Bos taurus cattle using PCR-RFLP. J. Anim. Vet. Adv. 9(11): 1660-1663.

Nei, M. and S. Kumar. 2000. Molecular Evolution and Phylogenetics. Oxford University Press. New York.

Oner, T., O. Yilmaz, H. Okut, N. Ata, G. Yilmazbas-Mecitoglu and A. Keskin. 2017. Associations between GH, PRL, STAT5A, $O P N, \quad P I T-1, \quad L E P, \quad$ and FGF2 polymorphisms and fertility in HolsteinFriesian heifers. Kafkas. Univ. Vet. Fak. Derg. 23(4):527-534.
Ozdemir, M. 2012. Determination of Pit-1/HinfI polymorphism in Holstein and native EAR cattle raised as genetic resorce in Turkey. J. Anim. Plant. Sci. 22(1):25-28.

Ozdemir, M., M. Topal, and V. Aksakal. 2016. The relationships between performance traits and and the $\mathrm{bGH} / A l u \mathrm{I}$ and Pit-1/Hinf $\mathrm{I}$ polymorphisms in Holstein cows. Indian J. Anim. Res. 52(2):186-191.

Renaville, R., N. Gengler, E. Vrech, A. Prandi, S. Massart, C. Corradini, C. Bertozzi, F. Mortiaux, A. Burny and D. Portetelle. 1997a. Pit-1 Gene Polymorphism, Milk Yield, and Conformation Traits for Italian Holstein-Friesian Bulls. J. Dairy Sci. 80(12): 3431-3438.

Renaville, R., N. Gengler, I. Parmentier, F. Mortiaux, S. Massart, C. Bertozzi, A. Burny and D. Portetelle. 1997b. Pit-1 gene HinfI RFLP and growth traits in double-muscled Belgian Blue cattle. J. Anim. Sci. 75(1): 146.

Sadeghi, M., M. M. S. Babak, G. Rahimi and A. N. Javaremi. 2008. Association between gene polymorphism of bovine growth hormone and milk traits in the Iranian Holstein bulls. Asian. J. Anim. Sci. 2(1):1-6.

Selvaggi, M. and C. Dario. 2011. Analysis of two Pit-1 gene polymorphisms: Single nucleotide polymorphisms (SNPs) distribution patterns in Podolica cattle breed. Afric. J. Biotech. 10(55): 1136011364

Sumantri, C., M. Imron, Sugyono, E. Andreas, R. Misrianti and A.B.L. Ishak. 2011. Keragaman grup gen hormon pertumbuhan (GH, GHR, GHRH dan Pit-1) dan hubungannya dengan respon superovulasi, tingkat ovulasi, tingkat fertilisasi dan dan kualitas embrio sapi di Balai Embrio Ternak (BET) Cipelang. JITV. 16(2):126-139.

Trakovicka, A., N. Moravcikova, T. Minarovic, and A. Navratilova. 2015. SNPs analyses of the bovine LEP and PIT-1 genes by multiplex PCR-RFLP method and their effect on milk performance traits in Slovak Simmental cattle. J. Cent. Eur. Agric. 16(1):65-75.

Van Eenennaam, A. L., J. Li, R. M. Thallman, R. L. Quaas, M. E. Dikeman, C. A. Gill, D. E. Franke and M.G. Thomas. 2007. Validation of commercial DNA tests for quantitative beef quality traits. J. Anim. Sci. 891-900.

Vargas, L. D., V. E. Gana and I. F. Escudero. 
2004. Pit-1 gene polymorphism in dairy cows from Central Chile. Arch. Zootec. 53: 217-220.

Woollard, J., C. K. Tuggle and F. A. Poncede Leon. 2000. Rapid communication: Localization of POU1F1 to bovine, ovine, and caprine Iq21-22. J. Anim. Sci 78(1):242-242.

Yan, L. J., B. Liu, X. T. Fang, H. Chen, R. F. Zhang, B. Bao and H. J. Zhang. 2011.
Analysis of pituitary specific transcription factor-1 gene polymorphisms in several indigenous Chinese cattle and crossbred cattle. J. Appl. Anim. Res. 39(3):269-274.

Zhao, Q., M. E. Davis and H. C. Hines. 2004. Associations of polymorphisms in the Pit-1 gene with growth and carcass traits in Angus beef cattle. J. Anim. Sci. 82(8):22292233. 